\title{
Combined Therapy Can Improve the Outcomes of Breast Cancer with Isolated Supraclavicular Lymph Node Involvement
}

This article was published in the following Dove Press journal: Cancer Management and Research

\section{Tianyi Ma \\ Yan Mao \\ Haibo Wang}

Department of Breast Disease Center, The Affiliated Hospital of Qingdao University, Qingdao, People's Republic of China
Correspondence: Haibo Wang Department of Breast Disease Center, The Affiliated Hospital of Qingdao University, No. 16 Jiangsu Road, Qingdao 266000, People's Republic of China Email hbwang66@I26.com
Purpose: This study aimed to evaluate the efficacy of systemic combined with local therapies in isolated metachronous ipsilateral supraclavicular lymph node metastasis (mISLM) breast cancer patients.

Patients and Methods: We reviewed the data of mISLM patients admitted by Breast Disease Center of the Affiliated Hospital of Qingdao University, from January 2009 to July 2019. Ninety-nine patients were included and were divided into two groups: the systemic group, which referred to patients who received only systemic therapy, and the combined group, which referred to patients who received systemic therapy plus local therapy (including neck radiotherapy (RT) and/or supraclavicular lymph node dissection surgery). In the combined group, patients were further divided into systemic therapy plus: 1) neck RT, 2) supraclavicular lymph node dissection surgery, and 3) neck RT and supraclavicular lymph node dissection surgery.

Results: The median duration of follow-up was 36 months. The median PFS was 15 months, and the median OS was 35 months. Local control rates of 1 year, 2 years and 3 years were $92.9 \%, 86.9 \%$ and $84.8 \%$, respectively. The combined group $(n=56)$ had a significantly better PFS $(\mathrm{P}<0.001)$ and OS $(\mathrm{P}=0.001)$ than the systemic group $(\mathrm{n}=43)$. Compared with Group $B(n=13)$ and Group C $(n=14)$, Group A $(n=29)$ had a significantly better PFS $(P=0.007)$. Higher dose and conventional dose showed no significant differences regarding the local control rate $(\mathrm{P}=1.000)$, PFS $(\mathrm{P}=0.787)$ or $\mathrm{OS}(\mathrm{P}=0.690)$ in the patients who received $\mathrm{RT}$. In multivariate analysis, $\mathrm{pN} 3$ stage and combined therapy (systemic therapy plus local therapy) for mISLM affected PFS $(\mathrm{P}<0.001$ and $\mathrm{P}=0.002$, respectively). Neck RT was an independent parameter affecting OS $(\mathrm{P}=0.002)$.

Conclusion: In breast cancer patients with mISLM, systemic therapy combined with local therapy could improve PFS and OS. Based on systemic therapy, RT had a better effect on survival than surgery. However, more aggressive methods, such as systemic therapy combined with both RT and surgery or a higher dose of RT, may not be associated with improved PFS or OS in these patients.

Keywords: breast cancer, supraclavicular lymph node metastasis, supraclavicular lymph node dissection, radiotherapy

\section{Introduction}

Currently, breast cancer is the most common cancer in women. Clinically, the incidence of isolated ipsilateral supraclavicular lymph node metastasis (ISLM) in breast cancer is $1-5 \%{ }^{1,2}$ ISLM is a difficult problem for clinical doctors. The appearance of ISLM is often considered a sign of poor prognosis. Most patients 
have distant metastasis within 1 year after diagnosis, and the median survival time is $2-4$ years. ${ }^{3}$ ISLM can be divided into two types: synchronous ISLM (sISLM) and metachronous ISLM (mISLM). sISLM is defined as ISLM at the time of primary diagnosis of breast cancer, and mISLM is defined as the occurrence of supraclavicular lymph node metastasis after the initial diagnosis and treatment of breast cancer. Studies have shown that clinical outcomes are similar for sISLM patients and mISLM patients. $^{4}$

In the TNM staging system of the American Joint Committee on Cancer (AJCC), the assessment of ISLM patients has experienced significant changes. ${ }^{5}$ In the 6 th edition of the AJCC TNM staging system, breast cancer with ISLM was reclassified as stage N3c instead of M1, which suggested that ISLM was a regional disease rather than a type of distant metastasis. ${ }^{6}$ As a result, more aggressive treatment options were used in these patients. ${ }^{7}$ Most studies have shown that when systemic therapy was combined with local therapy, the risk of disease progression was significantly reduced. ${ }^{2,4}$ However, studies comparing the outcomes of supraclavicular lymph node dissection surgery and neck radiotherapy (RT) were rare and no concrete guidelines were provided to support such patients. Controversy existed in how to choose the optimal therapy strategy.

Hence, the purpose of this study was to further clarify the efficacy of local therapies for the prognosis of isolated mISLM patients and to reveal the potential difference between RT and surgery, hoping to provide additional insight into clinical practice.

\section{Patients and Methods}

\section{Study Population}

In this study, we reviewed breast cancer patients who were diagnosed with isolated mISLM and treated at the Breast Disease Center of the Affiliated Hospital of Qingdao University, from January 2009 to July 2019. Based on a Roman numeral "level" system classification (from I, II, III, IV, V, VI) by AJCC, the anatomical location of supraclavicular lymph nodes is located in level IV and sublevel $\mathrm{Vb}$. Isolated mISLM was defined as the absence of distant metastasis within 3 months of mISLM diagnosis. sISLM patients were excluded upfront. The eligibility criteria were female patients with histologically confirmed primary breast cancer who were diagnosed with isolated mISLM, patients who were $\leq 75$ years old, and patients for whom information regarding the treatment records was available. The exclusion criteria were patients who had contralateral breast cancer or inflammatory breast cancer, who had a previous history of breast cancer or other malignancies, and who had severe complications of other organs. Considering the influence on $\mathrm{M}$ stage, we excluded the patients who were suspected to have neck lymph node metastasis in levels I, II, III and VI.

A systemic survey included serum tumor markers, ultrasound scans of the liver, chest computed tomography (CT) scans, bone scans and brain magnetic resonance imaging (MRI) scans for all patients; positron emission computed tomography (PET-CT) was performed in selected patients. All patients' primary breast cancer and mISLM were pathologically confirmed. Positivity for estrogen receptor (ER) or progesterone receptor (PR) was defined as an Allred score of 3-8 on immunohistochemistry (IHC). Human epidermal growth factor receptor 2 (HER2) positivity was defined as either $3+$ on IHC staining or $2+$ on IHC with a positive fluorescence in situ hybridization or chromogenic in situ hybridization signal. The molecular subtype of each breast cancer was categorized as follows: $\mathrm{ER}+$ or $\mathrm{PR}+$, and HER2 - (luminal); ER+/-, PR+/-, and HER2+ (HER2 enriched); or ER-, $\mathrm{PR}-$, and HER2- (triple-negative).

\section{Treatment}

Treatments were performed according to national guidelines and the specific situation of the patients. Patients received standard treatment and regular follow-up after the diagnosis of primary breast cancer. They were followed every 6 months after breast surgery with physical examinations and imaging examinations. After the diagnosis of isolated mISLM, patients received individualized treatment. The systemic therapies included chemotherapy, endocrine therapy and/or targeted therapy against HER2. The local therapies included neck RT and/or supraclavicular lymph node dissection surgery (including the fat and lymph nodes in the lower part of level III, level IV, and sublevel $\mathrm{Vb}$ ). And combined therapy referred to that the patient had received both systemic and local therapies. According to different management strategies, the patients were divided into two groups: the systemic group, which referred to patients who received only systemic therapy, and the combined group, which referred to patients who received combined therapy. And in the combined group, patients were divided into three groups according to the different local therapies: 1) systemic therapy plus neck RT; 2) systemic therapy plus supraclavicular lymph node 
dissection surgery; and 3) systemic therapy plus neck RT and supraclavicular lymph node dissection surgery. The follow-up interval was 2 months, and the main examination method was neck ultrasound. CT and MRI were used as auxiliary methods. The timing of the systemic examinations depended on the curative effect of the supraclavicular lymph nodes. Additional studies were performed in patients with suspicious clinical signs or symptoms.

\section{Statistical Analysis}

The time interval between the initial diagnosis of primary breast cancer and the diagnosis of isolated MISLM was considered disease-free survival (DFS). The diagnosis of isolated mISLM was considered the starting point of progression-free survival (PFS), and the progression of mISLM or the appearance of distant metastasis was considered the endpoint of PFS. The time interval between the initial treatment of metastatic supraclavicular lymph nodes and death from any cause or the last follow-up was considered overall survival (OS). The actuarial survival rates were calculated by the Kaplan-Meier method and compared using the Log rank test. In multivariate analysis, the Cox proportional hazards model was applied. Factors with a p-value $<0.05$ in univariate analysis were included in the multivariate analysis. A $\mathrm{p}<0.05$ was considered statistically significant. Differences in categorical variables were compared using the standard chi-square test or Fisher's exact test. All statistical analyses were performed using SPSS software (version 17.0.1. SPSS Inc., Chicago, IL).

\section{Ethical Statement}

The experimental protocols were approved by the institutional review committee of the Affiliated Hospital of Qingdao University and meet the guidelines of a governmental agency. All patients provided informed consent, and this study was conducted in accordance with the Declaration of Helsinki.

\section{Results}

\section{Cohort Survey}

In our database, there were 13,847 breast cancer patients from January 2009 to July 2019, including 125 mISLM patients. Then, 99 isolated mISLM patients satisfied the criteria and were screened out. The process of screening and grouping is shown in Figure 1. In general, we observed that the incidence rate of mISLM was about
$0.9 \%$. All patients were female with a median age of 53 years (range 33-74 years). The median DFS of these patients was 24 months (range, 2 to 168 months). The median duration of follow-up for the 99 patients was 36 months (range, 5 to 110 months). Thirty-nine (39.4\%) patients had reported local symptoms prior to ISLM verification. Among all 99 patients, 36 (36.4\%) patients received fine-needle biopsy, 49 (49.5\%) received coreneedle biopsy, and 14 (14.1\%) received excisional biopsies under local anesthesia. The pathological types of primary breast cancer were nonspecific invasive ductal carcinoma $(90,90.9 \%)$, as well as invasive lobular carcinoma (6, $6.1 \%$ ) and mucinous carcinoma $(3,3.0 \%)$. In terms of the pathological types of primary breast cancer, luminal patients were the most common $(39,39.4 \%)$, followed by triple-negative patients $(30,30.3 \%)$ and HER2-enriched patients $(30,30.3 \%)$. The results of ISLM immunohistochemistry in 16 patients were not consistent with those of primary breast cancers. The most common change was from the luminal type to the triple-negative type (11, $68.8 \%$ ). Of all 99 patients, $72(72.7 \%)$ patients had progression during follow-up and 44 (44.4\%) patients died. Sixteen patients had ISLM progression, 14 patients had contralateral axillary or supraclavicular lymph node metastasis, and 42 patients had distant organ metastasis. The most common organ of metastasis was bone (25/42, 59.5\%). The median PFS of these 99 patients was 15 months (range, 4 to 69 months), and the median OS was 35 months (range, 5 to 115 months). The 1-year, 2-year and 3-year local control rates, PFS rates and OS rates are shown in Table 1.

\section{Survival Analysis of Patients in the Systemic Group and the Combined Group}

Regarding the treatment strategies, the systemic group and the combined group included $43(43.4 \%)$ and 56 (56.6\%) patients, respectively. Table 2 shows the comparison of characteristics between patients in the systemic group and the combined group. There was no significant difference between the two groups in terms of age, and details of primary breast cancer such as $\mathrm{T}$ stage, $\mathrm{pN}$ stage, breast surgery type, pathology, histological grade, molecular subtype or adjuvant RT. The median DFS of the systemic group was 26 months (range, 2 to 168 months), and the median DFS of the combined group was 23.5 months (range, 2 to 120 months). 


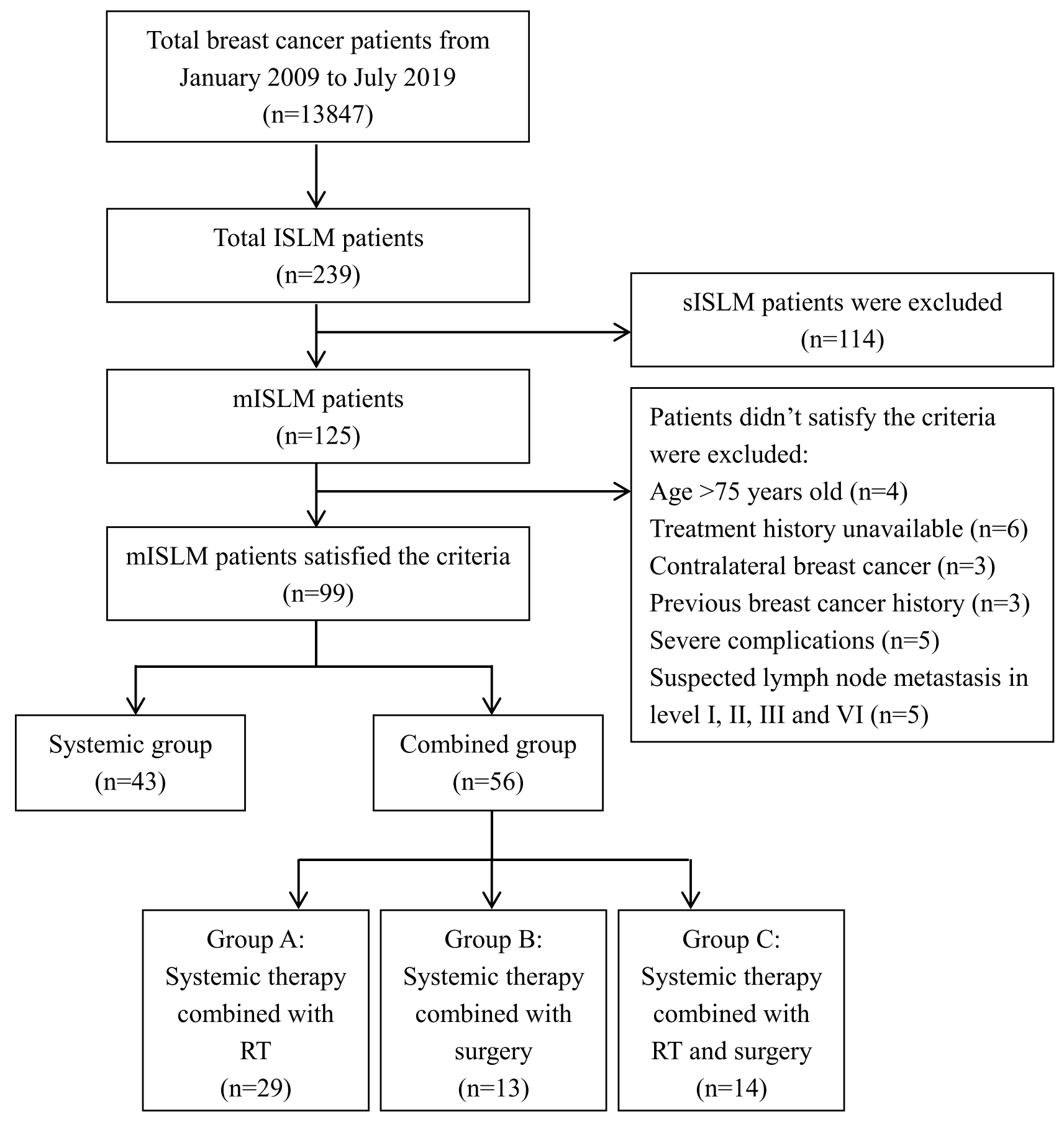

Figure I The procedure of screening and grouping patients.

Abbreviations: ISLM, ipsilateral supraclavicular lymph node metastasis; sISLM, synchronous ISLM; mISLM, metachronous ISLM; RT, radiotherapy.

The median PFS of the systemic group was 10 months (range, 4 to 63 months), and the median PFS of the combined group was 16.5 months (range, 5 to 69 months). The median OS of the systemic group was 28 months (range, 5 to 89 months), and the median OS of the combined group was 40 months (range, 13 to 112 months). The 3-year OS of the systemic group and combined group were $62.8 \%(27 / 43)$ and $87.5 \%(49 / 56)$, respectively.

Kaplan-Meier survival curves with the Log rank test for PFS and OS were performed, and the results are presented in Figure 2. The survival analyses indicated that the combined group had a significantly better PFS $(\mathrm{P}<0.001)$ and OS $(\mathrm{P}=0.001)$ than the systemic group. 
Table I The Local Control Rates, PFS Rates and OS Rates

\begin{tabular}{|l|l|l|l|l|l|l|l|l|l|}
\hline \multirow{2}{*}{} & \multicolumn{2}{l}{ Local Control } & \multicolumn{2}{l|}{ PFS } & \multicolumn{2}{l|}{ OS } \\
\cline { 2 - 10 } & I-Year & 2-Year & 3-Year & I-Year & 2-Year & 3-Year & I-Year & 2-Year & \multicolumn{2}{l|}{ 3-Year } \\
Rate, \% & Rate, \% & Rate, \% & Rate, \% & Rate, \% & $\begin{array}{l}\text { Rate, \% } \\
\text { Rate, \% }\end{array}$ & Rate, \% & Rate, \% \\
\hline Total & 92.9 & 86.9 & 84.8 & 70.7 & 46.5 & 41.4 & 97.0 & 92.9 & 76.8 \\
Systemic group & 90.7 & 79.1 & 79.1 & 60.5 & 37.2 & 27.9 & 93.0 & 90.7 & 62.8 \\
Combined group & 92.9 & 91.1 & 87.5 & 78.6 & 53.6 & 50.0 & 100 & 94.6 & 87.5 \\
Group A & 96.6 & 96.6 & 93.1 & 89.7 & 75.9 & 72.4 & 100 & 100 & 100 \\
Group B & 92.3 & 84.6 & 84.6 & 69.2 & 30.8 & 30.8 & 100 & 84.6 & 69.2 \\
Group C & 92.9 & 92.9 & 85.7 & 64.3 & 35.7 & 28.6 & 100 & 92.9 & 78.6 \\
\hline
\end{tabular}

Abbreviations: PFS, progression-free survival; OS, overall survival.

\section{Comparison Between Patients with Different Local Therapies}

In total, 56 patients underwent combined therapy (systemic therapy plus local therapy). The median duration of follow-up was 40 months (range, 8 to 110 months). In the combined group, 29 (51.8\%), 13 (23.2\%) and 14 (25.0\%) patients were divided into Group A, Group B and Group C, respectively. Table 3 shows the comparison of patients' characteristics in Groups A, B, and C. There was no significant difference among these three types of patients in terms of age and details of primary breast cancer such as $\mathrm{T}$ stage, $\mathrm{pN}$ stage, breast surgery type, pathology, histological grade, molecular subtype or adjuvant RT.

The median PFS of Group A was 31 months (range, 5 to 69 months), the median PFS of Group B was 15 months (range, 6 to 45 months), and the median PFS of Group C was 14.5 months (range, 9 to 40 months); The median OS of these three types of patients was 43 months (range, 13 to 112 months), 36 months (range, 13 to 80 months), and 35.5 months (range, 14 to 81 months) respectively. And the 3-year OS rates of them were 100\% (29/29), $69.2 \%(9 / 13)$ and $78.6 \%(11 / 14)$, respectively.

Kaplan-Meier survival curves with the Log rank test for PFS and OS were performed, and the results are presented in Figure 3. The survival analyses indicated that Group A had a significantly better PFS than Group B and Group $\mathrm{C}(\mathrm{P}=0.007)$. However, there was no significant difference in OS among the three Groups $(\mathrm{P}=0.250)$. The PFS $(\mathrm{P}=0.966)$ and OS $(\mathrm{P}=0.839)$ between Group $\mathrm{B}$ and Group $\mathrm{C}$ were not obviously different.

\section{Comparison Between Different RT Doses}

In Group A (patients who received systemic therapy plus neck RT), 14 of the 29 patients did not receive adjuvant RT. After the diagnosis of ISLM, the
Table 2 Comparison of Patient Characteristics Between Systemic Group and Combined Group

\begin{tabular}{|c|c|c|c|c|}
\hline \multicolumn{2}{|c|}{ Characteristics } & \multicolumn{2}{|c|}{ Number of Patients (\%) } & \multirow[t]{2}{*}{ p value } \\
\hline & & $\begin{array}{l}\text { Systemic } \\
\text { Group } \\
(n=43)\end{array}$ & $\begin{array}{l}\text { Combined } \\
\text { Group } \\
(n=56)\end{array}$ & \\
\hline Age (years) & $\begin{array}{l}<50 \\
\geq 50\end{array}$ & $\begin{array}{l}8(18.6) \\
35(81.4)\end{array}$ & $\begin{array}{l}14(25.0) \\
42(75.0)\end{array}$ & 0.448 \\
\hline T stage & $\begin{array}{l}1 \\
2 \\
3\end{array}$ & $\begin{array}{l}\text { II (25.6) } \\
28(65.1) \\
4(9.3)\end{array}$ & $\begin{array}{l}19(33.9) \\
28(50.0) \\
9(16.1)\end{array}$ & 0.808 \\
\hline $\mathrm{pN}$ stage & $\begin{array}{l}0 \\
1 \\
2 \\
3\end{array}$ & $\begin{array}{l}10(23.3) \\
12(27.9) \\
8(18.6) \\
13(30.2)\end{array}$ & $\begin{array}{l}12(21.4) \\
19(33.9) \\
12(21.4) \\
13(23.2)\end{array}$ & 0.696 \\
\hline Breast surgery & $\begin{array}{l}\text { Mastectomy } \\
\text { BCS }\end{array}$ & $\begin{array}{l}39(90.7) \\
4(9.3)\end{array}$ & $\begin{array}{l}49(87.5) \\
7(12.5)\end{array}$ & 0.858 \\
\hline Pathology & $\begin{array}{l}\text { IDC } \\
\text { Others }\end{array}$ & $\begin{array}{l}39(90.7) \\
4(9.3)\end{array}$ & $\begin{array}{l}51(91.1) \\
5(8.9)\end{array}$ & 0.949 \\
\hline $\begin{array}{l}\text { Histologic } \\
\text { grade }\end{array}$ & $\begin{array}{l}2 \\
3\end{array}$ & $\begin{array}{l}20(46.5) \\
23(53.5)\end{array}$ & $\begin{array}{l}31(55.4) \\
25(44.6)\end{array}$ & 0.385 \\
\hline $\begin{array}{l}\text { Molecular } \\
\text { subtype }\end{array}$ & $\begin{array}{l}\text { Luminal } \\
\text { HER2- } \\
\text { enriched } \\
\text { Triple- } \\
\text { negative }\end{array}$ & $\begin{array}{l}16(37.2) \\
12(27.9) \\
15(34.9)\end{array}$ & $\begin{array}{l}23(41.1) \\
18(32.1) \\
15(26.8)\end{array}$ & 0.683 \\
\hline $\begin{array}{l}\text { Adjuvant } \\
\text { radiotherapy }\end{array}$ & $\begin{array}{l}\text { Yes } \\
\text { No }\end{array}$ & $\begin{array}{l}15(34.9) \\
28(65.1)\end{array}$ & $\begin{array}{l}27(48.2) \\
29(51.8)\end{array}$ & 0.183 \\
\hline $\begin{array}{l}\text { Type of } \\
\text { systemic } \\
\text { therapy after } \\
\text { ISLM }\end{array}$ & $\begin{array}{l}\text { Only CT } \\
\text { Only ET } \\
C T+E T \\
C T+\text { anti- } \\
\text { HER2 drugs }\end{array}$ & $\begin{array}{l}20(46.5) \\
9(20.9) \\
6(14.0) \\
8(18.6)\end{array}$ & $\begin{array}{l}26(46.4) \\
4(7.1) \\
14(25.0) \\
12(21.4)\end{array}$ & 0.162 \\
\hline
\end{tabular}

Abbreviations: T, tumor; LN, lymph node; BCS, breast-conserving surgery; IDC, invasive ductal carcinoma; HER2, human epidermal growth factor receptor 2; ISLM, ipsilateral supraclavicular lymph node metastasis; CT, chemotherapy; ET, endocrine therapy. 

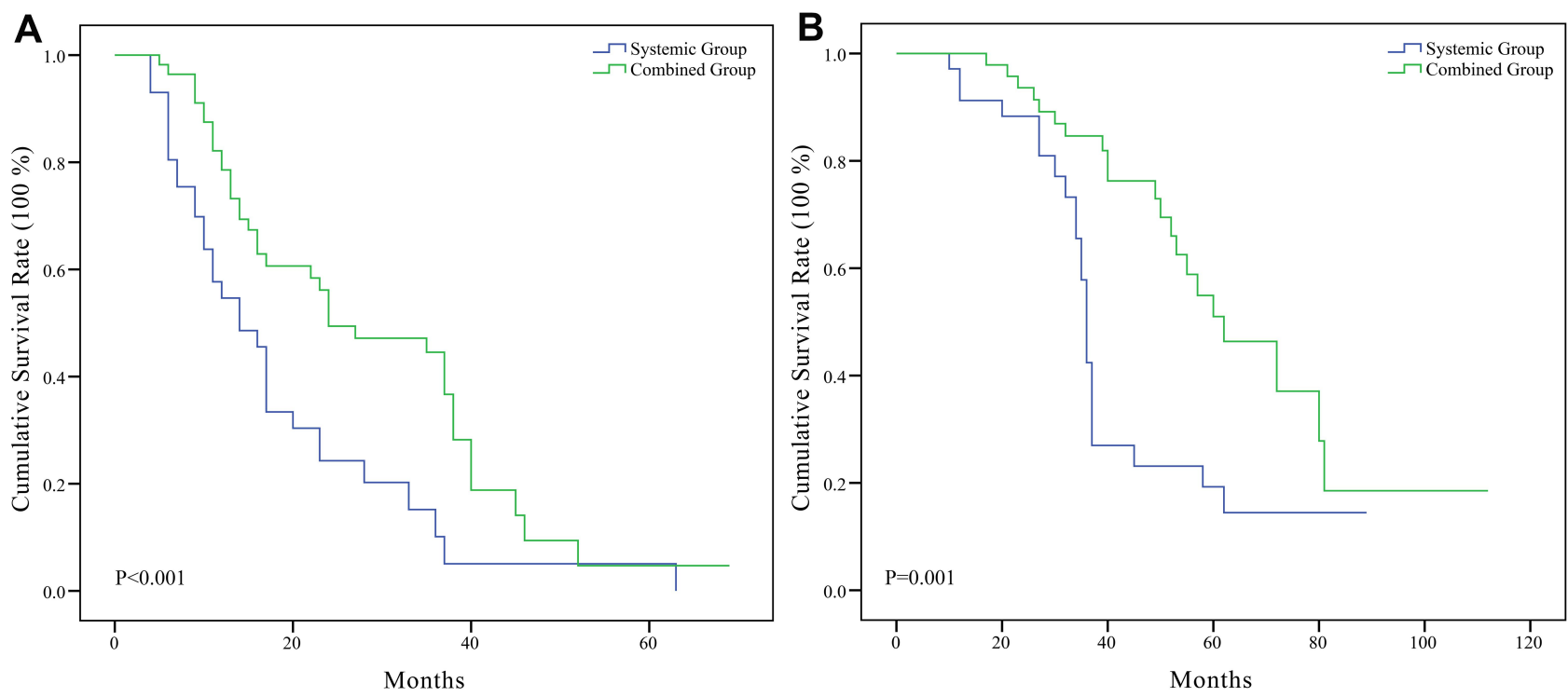

Figure 2 (A) Kaplan-Meier curves showed the difference of progression-free survival rate between systemic group and combined group, P<0.00I. (B) Kaplan-Meier curves showed the difference of overall survival rate between systemic group and combined group, $\mathrm{P}=0.00 \mathrm{I}$.

14 patients received RT including chest wall, axilla, infraclavicular and supraclavicular areas. The radiation dose was $50 \mathrm{~Gy}$. The other 15 patients received adjuvant RT. Three of them were at pN0 stage after breastconserving surgeries and received only breast adjuvant RT without supraclavicular area. After the diagnosis of ISLM, these three patients received RT including chest wall axilla, infraclavicular and supraclavicular areas, but avoided the target area of former adjuvant RT. And the cumulative radiation dose of these 3 patients was $50 \mathrm{~Gy}$. The other 12 patients were at $\mathrm{pN} 1-3$ stage after primary surgery, and they received adjuvant RT including chest wall, axilla, infraclavicular and supraclavicular areas. Their adjuvant RT dose was 50 Gy. After the diagnosis of ISLM, these 12 patients received RT of a local increased dose of 10-20 Gy. Totally, 17 (58.6\%) patients received a conventional dose of $50 \mathrm{~Gy}$, while $12(41.4 \%)$ received a boost of 10-20 Gy. KaplanMeier survival curves and survival analyses showed that the PFS $(\mathrm{P}=0.787)$ and $\mathrm{OS}(\mathrm{P}=0.690)$ between the conventional dose and boost dose were similar. Simultaneously, it was found that the local control effects were similar $(\mathrm{P}=1.000)$. The proportion of patients with a complete response (CR) or partial response (PR) in the conventional dose group (12/17, $70.6 \%$ ) was not obviously different from that in the boost dose group $(9 / 12,75.0 \%)$.

Of the 14 patients who received systemic therapy combined with RT and surgery, 8 (57.1\%) patients received a conventional dose, and $6(42.9 \%)$ received a boost dose. Due to the small number of cases and short follow-up time, survival analysis was not available. However, the conclusion can be drawn that the local control effects had the same tendency. The proportion of patients with a CR or PR in the conventional dose group $(5 / 8,62.5 \%)$ was similar to that in the boost dose group $(4 / 6,66.7 \%)$.

\section{Univariate and Multivariate Analyses for PFS and OS}

The univariate analysis of PFS showed that age of patients, pN stage at primary breast cancer diagnosis, therapy strategy of supraclavicular lymph nodes and neck RT were significant factors $(\mathrm{P}=0.044, \mathrm{P}=0.002, \mathrm{P}=0.048$ and $\mathrm{P}=0.003$, respectively). For $\mathrm{OS}$, the univariate analysis showed that the $\mathrm{pN}$ stage at primary breast cancer diagnosis, therapy strategy of supraclavicular lymph nodes and neck RT were also significant factors $(\mathrm{P}=0.033, \mathrm{P}=0.004$ and $\mathrm{P}=0.001$, respectively). In the multivariate analysis, pN3 stage $(\mathrm{P}<0.001, \mathrm{HR}=2.872)$ and combined therapy (systemic therapy plus local therapy, $\mathrm{P}=0.002$, $\mathrm{HR}=0.429$ ) for supraclavicular lymph nodes were independent parameters for PFS. Additionally, neck RT was an independent parameter affecting OS. The absence of neck RT would produce a negative impact on the OS of ISLM patients $(\mathrm{P}=0.002, \mathrm{HR}=6.700)$. The relevant statistics are shown in Table 4. 
Table 3 Comparison of Patient Characteristics Between Different Local Therapies

\begin{tabular}{|c|c|c|c|c|c|}
\hline \multicolumn{2}{|l|}{ Characteristics } & \multicolumn{3}{|c|}{ Number of Patients (\%) } & \multirow{3}{*}{$\begin{array}{l}\text { P value } \\
0.103\end{array}$} \\
\hline & & \multirow{2}{*}{$\begin{array}{l}\text { Radiotherapy }(n= \\
29) \\
4(13.8) \\
25(86.2)\end{array}$} & \multirow{2}{*}{$\begin{array}{l}\text { Surgery }(n= \\
\text { 13) } \\
4(30.8) \\
9(69.2)\end{array}$} & \multirow{2}{*}{$\begin{array}{l}\text { Radiotherapy and Surgery (n } \\
=14) \\
6(42.9) \\
8(57.1)\end{array}$} & \\
\hline Age (years) & $\begin{array}{l}<50 \\
\geq 50\end{array}$ & & & & \\
\hline T stage & $\begin{array}{l}1 \\
2 \\
3\end{array}$ & $\begin{array}{l}\text { II (37.9) } \\
\text { I4 (48.3) } \\
4(13.8)\end{array}$ & $\begin{array}{l}4(30.8) \\
7(53.8) \\
2(15.4)\end{array}$ & $\begin{array}{l}4(28.6) \\
7(50.0) \\
3(21.4)\end{array}$ & 0.746 \\
\hline $\mathrm{pN}$ stage & $\begin{array}{l}0 \\
1 \\
2 \\
3\end{array}$ & $\begin{array}{l}7(24.1) \\
10(34.5) \\
6(20.7) \\
6(20.7)\end{array}$ & $\begin{array}{l}1(7.7) \\
5(38.5) \\
2(15.4) \\
5(38.5)\end{array}$ & $\begin{array}{l}4(28.6) \\
4(28.6) \\
4(28.6) \\
2(14.3)\end{array}$ & 0.349 \\
\hline Breast surgery & $\begin{array}{l}\text { Mastectomy } \\
\mathrm{BCS}\end{array}$ & $\begin{array}{l}25(86.2) \\
4(13.8)\end{array}$ & $\begin{array}{l}12(92.3) \\
\mathrm{I}(7.7)\end{array}$ & $\begin{array}{l}12(85.7) \\
2(14.3)\end{array}$ & 0.821 \\
\hline Pathology & $\begin{array}{l}\text { IDC } \\
\text { Others }\end{array}$ & $\begin{array}{l}26(89.7) \\
3(10.3)\end{array}$ & $\begin{array}{l}\text { I } 2(92.3) \\
\text { I (7.7) }\end{array}$ & $\begin{array}{l}\text { I3 (92.9) } \\
\text { I (7.I) }\end{array}$ & 0.927 \\
\hline Histologic grade & $\begin{array}{l}2 \\
3\end{array}$ & $\begin{array}{l}16(55.2) \\
13(44.8)\end{array}$ & $\begin{array}{l}7(53.8) \\
6(46.2)\end{array}$ & $\begin{array}{l}8(57.1) \\
6(42.9)\end{array}$ & 0.985 \\
\hline Molecular subtype & $\begin{array}{l}\text { Luminal } \\
\text { HER2-enriched } \\
\text { Triple-negative }\end{array}$ & $\begin{array}{l}9(31.0) \\
11(37.9) \\
9(31.0)\end{array}$ & $\begin{array}{l}7(53.8) \\
3(23.1) \\
3(23.1)\end{array}$ & $\begin{array}{l}7(50.0) \\
4(28.6) \\
3(21.4)\end{array}$ & 0.621 \\
\hline Adjuvant radiotherapy & $\begin{array}{l}\text { Yes } \\
\text { No }\end{array}$ & $\begin{array}{l}15(51.7) \\
14(48.3)\end{array}$ & $\begin{array}{l}8(61.5) \\
5(38.5)\end{array}$ & $\begin{array}{l}4(28.6) \\
10(71.4)\end{array}$ & 0.190 \\
\hline $\begin{array}{l}\text { Type of systemic therapy after } \\
\text { ISLM }\end{array}$ & $\begin{array}{l}\text { Only CT } \\
\text { Only ET } \\
\mathrm{CT}+\mathrm{ET} \\
\mathrm{CT}+\text { anti-HER2 } \\
\text { drugs }\end{array}$ & $\begin{array}{l}15(51.7) \\
1(3.4) \\
6(20.7) \\
7(24.1)\end{array}$ & $\begin{array}{l}8(61.5) \\
1(7.7) \\
2(15.4) \\
2(15.4)\end{array}$ & $\begin{array}{l}3(2 \mid .4) \\
2(14.3) \\
6(42.9) \\
3(21.4)\end{array}$ & 0.315 \\
\hline
\end{tabular}

Abbreviations: T, tumor; LN, lymph node; BCS, breast-conserving surgery; IDC, invasive ductal carcinoma; HER2, human epidermal growth factor receptor 2; ISLM, ipsilateral supraclavicular lymph node metastasis; CT, chemotherapy; ET, endocrine therapy.

\section{Discussion}

In terms of anatomical structure, supraclavicular lymph nodes are closely related to the prognosis of breast cancer. ${ }^{8}$ With the development of imaging and pathological technologies, mISLM is increasingly diagnosed in locally advanced breast cancers. However, at present, there are few studies on the treatment strategy of mISLM breast cancer patients.

In this study, we retrospectively collected data from 99 mISLM patients and analyzed the therapeutic effect and survival. After survival analysis, we found that in mISLM patients, the combination of systemic therapy (including chemotherapy, endocrine therapy and/or targeted therapy against HER2) and local therapy (including neck RT and/ or supraclavicular lymph node dissection surgery) had a significantly better effect on PFS and OS than the use of systemic therapy alone. And the multivariate analyses indicated that the combined therapy of supraclavicular lymph nodes was an independent parameter for PFS, which confirmed that the combined therapy can reduce the possibility of tumor progression. These findings supported that combined therapy can improve the survival outcomes of mISLM patients and were in agreement with those of current mainstream studies. ${ }^{9-12}$ Additionally, we found in the multivariate analyses that the pN3 stage was an important factor affecting PFS. This indicated that ISLM patients with pN3 stage had a higher risk of supraclavicular lymph node failure and were more 

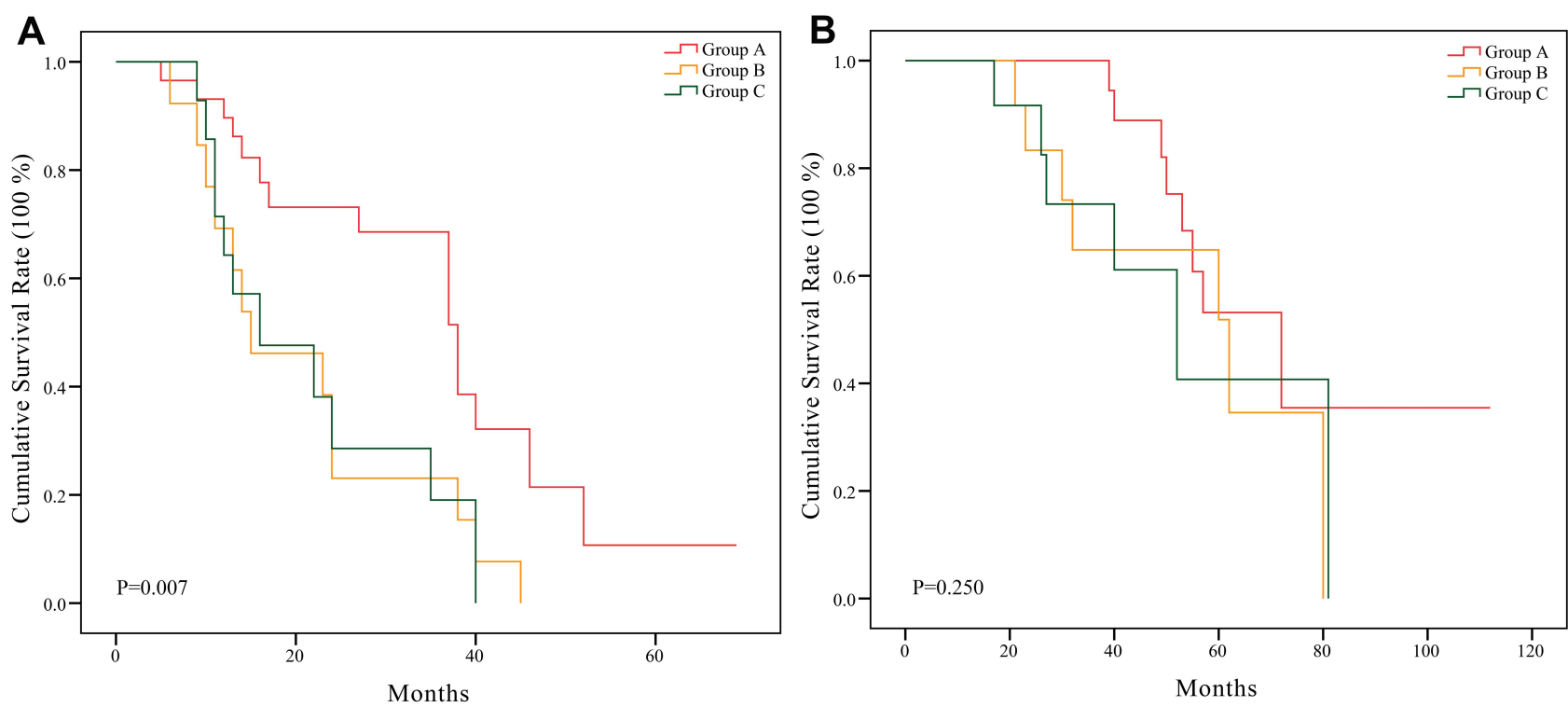

Figure 3 (A) Kaplan-Meier curves showed the difference of progression-free survival rate among Group A, B, and C, P=0.007. (B) Kaplan-Meier curves showed the difference of overall survival rate among Group $A, B$, and $C, P=0.250$.

likely to develop disease progression, which was also consistent with the previous results of Fan et al. And this may be related to the micrometastasis of tumor cells in supraclavicular vessels. ${ }^{4}$

In terms of local treatments, the median PFS (31 months versus 15 months) and median OS (43 months versus 36 months) of Group A were better than those of Group B. The survival analyses indicated that RT had a significantly better PFS than surgery. The advantages of RT on OS were not observed in survival analyses. We considered that this was probably related to the small number of surgical patients and the short follow-up time. Additionally, in the multivariate analysis, neck RT was an independent parameter affecting $\mathrm{OS}(\mathrm{P}=0.002)$. All the above results indicated that neck RT was beneficial to the survival of patients with ISLM, and it was superior to neck surgery. The most aggressive treatment, systemic therapy combined with both RT and surgery, did not show a better effect. We believe that this result was probably related to the prolonged interruption of chemotherapy caused by RT and surgery. Previous studies have shown that surgery combined with RT can improve the local control rate but that it has little contribution to overall survival. The main reason for failure was distant metastasis. Additionally, we observed that the boost dose and the conventional dose in RT had no significant difference in terms of the local control rate, PFS or OS. Therefore, we believe that the high dose of neck RT may be excessive.
In the previous studies, how to choose local treatment was always controversial. Although operations can completely remove metastatic lymph nodes and help surgeons obtain more complete pathological data, the disadvantages of operations cannot be ignored. Some patients may experience neuromuscular injury, lymphatic leakage, lymphatic reflux or other complications after surgery. ${ }^{13}$ Moreover, because of the special anatomic position of supraclavicular lymph nodes, it is difficult to determine the scope of surgical excision. Sesterhenn et al pointed out that the metastasis of neck lymph nodes in level III was not isolated, but often associated with IV level metastasis. ${ }^{14}$ This indicates that the location of supraclavicular lymph nodes cannot always be clearly located in clinical practice. Clinicians have reported noticeable variations in their opinions regarding the choice of surgical scope. According to a multicenter study from the UK, for patients with $\mathrm{N} 3 \mathrm{c}$ stage disease, $23.9 \%$ of clinicians preferred modified radical neck dissection (28/117), 12.8\% of clinicians recommended full jugular chain and level V surgery (15/117), and $35.0 \%$ of clinicians did not recommend neck surgery $(41 / 117){ }^{15}$

At the same time, whether neck surgery can improve the survival and prognosis of patients is still controversial. Chen reported 127 ISLM patients, 49 of whom received neck IV and partial III and V lymph node dissection, with 5 -year and 10 -year OS rates of $30.6 \%$ and $16.1 \%$, respectively, which were significantly higher than those without neck dissection (14\% and 4\%). ${ }^{16}$ However, some studies have shown opposite results. Jung et $\mathrm{al}^{17}$ found in the 
Table 4 Univariate and Multivariate Analysis for PFS and OS

\begin{tabular}{|c|c|c|c|c|c|c|c|c|}
\hline \multirow[t]{2}{*}{ Variables } & \multicolumn{4}{|l|}{ PFS } & \multicolumn{4}{|l|}{ os } \\
\hline & $\begin{array}{l}\text { 3-Year } \\
\text { Rate, \% }\end{array}$ & $\begin{array}{l}\text { P value } \\
\text { (Univariate) }\end{array}$ & $\begin{array}{l}\text { Hazard Ratio } \\
(95 \% \mathrm{Cl})\end{array}$ & $\begin{array}{l}\text { P value } \\
\text { (Multivariate) }\end{array}$ & $\begin{array}{l}\text { 3-Year } \\
\text { Rate, \% }\end{array}$ & $\begin{array}{l}\text { P value } \\
\text { (Univariate) }\end{array}$ & $\begin{array}{l}\text { Hazard Ratio } \\
(95 \% \mathrm{Cl})\end{array}$ & $\begin{array}{l}\text { P value } \\
\text { (Multivariate) }\end{array}$ \\
\hline $\begin{array}{l}\text { Age (years) } \\
\quad<50 \\
\geq 50\end{array}$ & $\begin{array}{l}22.7 \\
46.8\end{array}$ & 0.044 & & 0.125 & $\begin{array}{l}72.7 \\
77.9\end{array}$ & 0.611 & & \\
\hline $\begin{array}{l}\text { T stage } \\
\text { । } \\
2-3\end{array}$ & $\begin{array}{l}30.0 \\
46.4\end{array}$ & 0.130 & & & $\begin{array}{l}70.0 \\
79.7\end{array}$ & 0.296 & & \\
\hline $\begin{array}{l}\text { pN stage } \\
0-2 \\
3\end{array}$ & $\begin{array}{l}50.7 \\
15.4\end{array}$ & 0.002 & $\begin{array}{l}1 \\
2.872 \\
(1.676-4.921)\end{array}$ & $<0.001$ & $\begin{array}{l}82.2 \\
61.5\end{array}$ & 0.033 & & 0.143 \\
\hline $\begin{array}{l}\text { Breast surgery } \\
\text { Mastectomy } \\
\text { BCS }\end{array}$ & $\begin{array}{l}42.0 \\
36.4\end{array}$ & 0.971 & & & $\begin{array}{l}79.5 \\
54.5\end{array}$ & 0.064 & & \\
\hline $\begin{array}{l}\text { Histologic grade } \\
2 \\
3\end{array}$ & $\begin{array}{l}39.2 \\
43.7\end{array}$ & 0.649 & & & $\begin{array}{l}72.5 \\
81.2\end{array}$ & 0.308 & & \\
\hline $\begin{array}{l}\text { Molecular } \\
\text { subtype } \\
\text { Luminal } \\
\text { HER2-enriched } \\
\text { Triple-negative }\end{array}$ & $\begin{array}{l}38.5 \\
40.0 \\
46.7\end{array}$ & 0.776 & & & $\begin{array}{l}74.4 \\
76.7 \\
80.0\end{array}$ & 0.860 & & \\
\hline $\begin{array}{l}\text { HR } \\
\text { Positive } \\
\text { Negative }\end{array}$ & $\begin{array}{l}35.8 \\
47.8\end{array}$ & 0.228 & & & $\begin{array}{l}73.6 \\
80.4\end{array}$ & 0.421 & & \\
\hline $\begin{array}{l}\text { HER-2 } \\
\text { Positive } \\
\text { Negative }\end{array}$ & $\begin{array}{l}40.0 \\
42.0\end{array}$ & 0.851 & & & $\begin{array}{l}76.7 \\
76.8\end{array}$ & 0.987 & & \\
\hline $\begin{array}{l}\text { Adjuvant } \\
\text { radiotherapy } \\
\text { Yes } \\
\text { No }\end{array}$ & $\begin{array}{l}40.5 \\
42.1\end{array}$ & 0.871 & & & $\begin{array}{l}71.4 \\
80.7\end{array}$ & 0.280 & & \\
\hline $\begin{array}{l}\text { Therapy strategy } \\
\text { Systemic therapy } \\
\text { Combined } \\
\text { therapy }\end{array}$ & $\begin{array}{l}30.2 \\
50.0\end{array}$ & 0.048 & $\begin{array}{l}\text { I } \\
0.429 \\
(0.254-0.724)\end{array}$ & 0.002 & $\begin{array}{l}62.8 \\
87.5\end{array}$ & 0.004 & & 0.364 \\
\hline $\begin{array}{l}\text { ISLM } \\
\text { chemotherapy } \\
\text { Yes } \\
\text { No }\end{array}$ & $\begin{array}{l}43.5 \\
28.6\end{array}$ & 0.292 & & & $\begin{array}{l}76.5 \\
78.6\end{array}$ & 1.000 & & \\
\hline $\begin{array}{l}\text { ISLM hormonal } \\
\text { therapy } \\
\text { Yes } \\
\text { No }\end{array}$ & $\begin{array}{l}35.9 \\
45.0\end{array}$ & 0.369 & & & $\begin{array}{l}71.9 \\
80.0\end{array}$ & 0.345 & & \\
\hline
\end{tabular}


Table 4 (Continued).

\begin{tabular}{|c|c|c|c|c|c|c|c|c|}
\hline \multirow[t]{2}{*}{ Variables } & \multicolumn{4}{|l|}{ PFS } & \multicolumn{4}{|l|}{ os } \\
\hline & $\begin{array}{l}\text { 3-Year } \\
\text { Rate, \% }\end{array}$ & $\begin{array}{l}\text { P value } \\
\text { (Univariate) }\end{array}$ & $\begin{array}{l}\text { Hazard Ratio } \\
(95 \% \mathrm{Cl})\end{array}$ & $\begin{array}{l}\text { p value } \\
\text { (Multivariate) }\end{array}$ & $\begin{array}{l}\text { 3-Year } \\
\text { Rate, \% }\end{array}$ & $\begin{array}{l}\text { p value } \\
\text { (Univariate) }\end{array}$ & $\begin{array}{l}\text { Hazard Ratio } \\
(95 \% \mathrm{Cl})\end{array}$ & $\begin{array}{l}\text { p value } \\
\text { (Multivariate) }\end{array}$ \\
\hline $\begin{array}{l}\text { ISLM } \\
\text { radiotherapy } \\
\text { Yes } \\
\text { No }\end{array}$ & $\begin{array}{l}58.1 \\
28.6\end{array}$ & 0.003 & & 0.191 & $\begin{array}{l}93.0 \\
64.3\end{array}$ & 0.001 & $\begin{array}{l}1 \\
6.700 \\
(1.989-22.569)\end{array}$ & 0.002 \\
\hline $\begin{array}{l}\text { Neck surgery } \\
\text { Yes } \\
\text { No }\end{array}$ & $\begin{array}{l}25.9 \\
47.2\end{array}$ & 0.055 & & & $\begin{array}{l}74.1 \\
77.8\end{array}$ & 0.698 & & \\
\hline
\end{tabular}

Abbreviations: PFS, progression-free survival; OS, overall survival; $\mathrm{Cl}$, confidence interval; T, tumor; LN, lymph node; BCS, breast-conserving surgery; HER2, human epidermal growth factor receptor 2; ISLM, ipsilateral supraclavicular lymph node metastasis; HR, hormone receptor.

study of 111 ISLM patients that the OS of patients undergoing local aggressive treatment (including breast surgery, axillary lymph node dissection, supraclavicular lymph node excision, RT and chemotherapy) was significantly higher $(\mathrm{P}=0.036)$, but the survival advantage of supraclavicular lymph node excision itself was uncertain. According to Jung's study, locoregional failure-free survival (LRFFS), distant failure-free survival (DFFS), or OS of patients undergoing supraclavicular lymph node excision were not significantly different from those without active surgery. ${ }^{17}$ Huang's study found that the benefit of neck lymph node surgery may be offset by the risk of distant metastasis. ${ }^{18}$ Nikpayam's study ${ }^{19}$ had a similar result that the radical lymph node surgery was not proven to be beneficial to survival. A trial from South Korea found that aggressive regional surgery did not improve locoregional control or survival. ${ }^{10}$ And in a recently published article, Ai et $\mathrm{al}^{20}$ conducted a study of 305 patients with ISLM and found that supraclavicular lymph node dissection may not be beneficial in improving survival for unselected breast cancer patients with ISLM. Furthermore, in a study of Zhang et al, experts found that the benefit of neck surgery in ISLM patients may be related to pathological classification. ${ }^{21}$ The main studies are listed in Table 5.

Compared with surgery, neck RT is more widely accepted. Although many problems had not been solved, experts preferred to recommend neck RT as a local treatment for ISLM patients. ${ }^{22-24}$ The incidence and severity of complications after RT are generally lower than those after neck surgery. ${ }^{25}$ Brito reported 70 cases of breast cancer with ISLM, indicating that RT played a positive role in local recurrence control in patients without supraclavicular lymph node dissection. ${ }^{26}$ And the study of Kim et al confirmed the positive effect of neck radiotherapy on the survival of ISLM patients. ${ }^{11}$ Some centers also analyzed the effects of high-dose RT. In theory, more aggressive treatments should be helpful for improving the local control rate. However, some studies have shown that high-dose RT in the supraclavicular region does not improve local control or survival rates; in contrast, this technique may increase the probability of brachial plexus injury. ${ }^{27-29}$ Skinner evaluated the effects of dose on local control and survival in 159 patients with isolated locoregional recurrence after mastectomy. The OS rate and locoregional control rate (LCR) were not significantly improved in the dose-escalation group. ${ }^{30}$ A retrospective study from China showed that there was no significant difference in the 3-year locoregional control rate between ISLM patients who were treated with radiotherapy at $\leq 50$ Gy and $>50 \mathrm{~Gy}^{28}$ And a multicenter study of 353 patients from South Korea showed that high-dose RT did not translate into survival benefits. ${ }^{11}$ These were also consistent with our preliminary study results of radiation dose.

The limitations of this study are as follows: First, there might have been potential biases, which are the typical shortcomings of retrospective studies. Due to the nonrandomized retrospective nature of the study, the treatment types of supraclavicular lymph nodes were not randomly assigned but were individually selected according to the patient's condition. The inevitable bias in the selection of treatment therefore limited the interpretation of the survival analysis. Second, because of the small sample size and short follow-up time, the ideal subgroup analysis could not be carried out, and some events that may have had an important impact on the survival analysis 
Table 5 Main Studies Mentioned in the Discussion

\begin{tabular}{|c|c|c|c|c|c|c|}
\hline Author & Year & Country & $\begin{array}{l}\text { Study } \\
\text { Design }\end{array}$ & $\begin{array}{l}\text { Case } \\
\text { Number }\end{array}$ & $\begin{array}{l}\text { Median Follow- } \\
\text { Up Duration }\end{array}$ & Main Outcomes \\
\hline $\mathrm{Fan}^{4}$ & 2010 & China & Retrospective & $\begin{array}{l}48 \mathrm{mISLM} \\
\text { and } 33 \\
\text { sISLM } \\
\text { patients }\end{array}$ & $\begin{array}{l}93 \text { months (range, } \\
22-293 \text { months) }\end{array}$ & $\begin{array}{l}\text { Axillary lymph node metastasis status and chemotherapy } \\
\text { after occurrence of ISLM were independent prognostic } \\
\text { predictors for mISLM patients. }\end{array}$ \\
\hline Bisase $^{15}$ & 2012 & UK & Questionnaire & $\begin{array}{l}\text { II7 } \\
\text { clinicians }\end{array}$ & l & $\begin{array}{l}\text { There was a noticeable variation in opinion for neck } \\
\text { lymph node dissection. }\end{array}$ \\
\hline Chen ${ }^{16}$ & 2010 & China & Retrospective & $\begin{array}{l}\text { I } 27 \text { ISLM } \\
\text { patients }\end{array}$ & Not mentioned & $\begin{array}{l}\text { ISLM patients who underwent neck dissection had } \\
\text { better } 5 \text {-year and } 10 \text {-year OS rates than those who did } \\
\text { not. }\end{array}$ \\
\hline Jung ${ }^{17}$ & 2015 & $\begin{array}{l}\text { South } \\
\text { Korea }\end{array}$ & Retrospective & $\begin{array}{l}\text { I I I ISLM } \\
\text { patients }\end{array}$ & Not mentioned & $\begin{array}{l}\text { Local aggressive treatment (including breast surgery, } \\
\text { axillary lymph node dissection, supraclavicular lymph } \\
\text { node excision, RT and chemotherapy) improved OS, but } \\
\text { the role of supraclavicular lymph node excision was } \\
\text { uncertain. }\end{array}$ \\
\hline Huang ${ }^{18}$ & 2007 & USA & Retrospective & $\begin{array}{l}\text { 7I ISLM } \\
\text { patients }\end{array}$ & $\begin{array}{l}3.7 \text { years (range, } \\
\text { I.0-24.0 years) }\end{array}$ & $\begin{array}{l}\text { The benefit of neck lymph node surgery may be offset by } \\
\text { the risk of distant metastasis. }\end{array}$ \\
\hline Nikpayam ${ }^{19}$ & 2015 & France & Retrospective & $\begin{array}{l}39 \text { ISLM } \\
\text { patients }\end{array}$ & $\begin{array}{l}24 \text { months (range, } \\
\text { I-59 months) }\end{array}$ & $\begin{array}{l}\text { Radical lymph node surgery was not proven to be } \\
\text { beneficial. }\end{array}$ \\
\hline $\mathrm{Kim}^{10}$ & 2020 & $\begin{array}{l}\text { South } \\
\text { Korea }\end{array}$ & Retrospective & $\begin{array}{l}\text { 9I ISLM } \\
\text { patients }\end{array}$ & $\begin{array}{l}72 \text { months (range, } \\
7-182 \text { months) }\end{array}$ & $\begin{array}{l}\text { Neither supraclavicular lymph node excision nor } \\
\text { supraclavicular lymph node RT dose } \geq 54 \text { Gy improved } \\
\text { locoregional control. }\end{array}$ \\
\hline $\mathrm{Ai}^{20}$ & 2020 & China & Retrospective & $\begin{array}{l}305 \text { ISLM } \\
\text { patients }\end{array}$ & $\begin{array}{l}36 \text { months (range, } \\
2-175 \text { months) }\end{array}$ & $\begin{array}{l}\text { Supraclavicular lymph node dissection may not beneficial } \\
\text { in improving survival for unselected breast cancer } \\
\text { patients with ISLM. }\end{array}$ \\
\hline Zhang ${ }^{21}$ & 2017 & China & Retrospective & $\begin{array}{l}90 \text { ISLM } \\
\text { patients }\end{array}$ & $\begin{array}{l}85 \text { months (range, } \\
6-111 \text { months) }\end{array}$ & $\begin{array}{l}\text { The benefit of neck surgery in ISLM patients may be } \\
\text { related to pathological classification. }\end{array}$ \\
\hline$W_{u^{28}}$ & 2014 & China & Retrospective & $\begin{array}{l}39 \text { ISLM } \\
\text { patients }\end{array}$ & 35 months & $\begin{array}{l}\text { No significant difference in the } 3 \text {-year locoregional } \\
\text { control rate was found between patients who were } \\
\text { treated with radiotherapy at } \leq 50 \text { Gy and }>50 \text { Gy. }\end{array}$ \\
\hline Park $^{29}$ & 2011 & $\begin{array}{l}\text { South } \\
\text { Korea }\end{array}$ & Retrospective & $\begin{array}{l}55 \mathrm{~N} 3 \mathrm{c} \\
\text { patients }\end{array}$ & $\begin{array}{l}38 \text { months (range, } \\
9-80 \text { months) }\end{array}$ & $\begin{array}{l}\text { Higher-dose RT was not associated with additional } \\
\text { survival gains in locoregional control or DFS. }\end{array}$ \\
\hline Skinner ${ }^{30}$ & 2013 & USA & Retrospective & $\begin{array}{l}\text { I59 LRR } \\
\text { patients }\end{array}$ & 94 months & $\begin{array}{l}\text { Radiation dose escalation did not improve locoregional } \\
\text { control rate. }\end{array}$ \\
\hline Kim ${ }^{\prime \prime}$ & 2019 & $\begin{array}{l}\text { South } \\
\text { Korea }\end{array}$ & Retrospective & $\begin{array}{l}\text { I } 36 \text { ISLM } \\
\text { patients }\end{array}$ & $\begin{array}{l}\text { 6I months (range, } \\
7-173 \text { months) }\end{array}$ & $\begin{array}{l}\text { A higher RT dose to ISLM was not associated with the } \\
\text { improved DFS. }\end{array}$ \\
\hline
\end{tabular}

Abbreviations: ISLM, ipsilateral supraclavicular lymph node metastasis; mISLM, metachronous ISLM; sISLM, synchronous ISLM; DFS, disease-free survival; PFS, progressionfree survival; OS, overall survival; RT, radiotherapy; LRR, local regional recurrence.

were not observed. Third, the study interval was very long and the development of systemic treatment was significant. Although our simple assessment indicated that the improvement of treatment methods had little impact on survival analysis, it can inevitably lead to some deviation. Last but not the least, the imaging evaluation of cervical lymph nodes mainly depended on ultrasound. The subjective judgment of imaging doctors might have affected the interpretation of the results. Nevertheless, this study provides some ideas and guidance for clinicians' decisions. Some new methods, such as concurrent 
chemoradiotherapy and CT-guided interstitial 125 I seed implantation for supraclavicular lymph node metastasis, are still undergoing experimentation. At the same time, with the increase in the adjuvant RT population, the complications and treatment resistance of secondary RT may affect the efficacy of RT. Some clinicians still hope to identify a direction for ISLM treatment in neck surgery. Further large-scale, randomized studies are needed to assess the benefits of neck surgery in ISLM patients; a trial is currently being conducted in China. ${ }^{31}$

\section{Conclusion}

In conclusion, in breast cancer patients with mISLM, systemic therapy combined with local therapy could improve PFS and OS. Based on systemic therapy, RT had a better effect on survival than surgery. However, more aggressive methods, such as systemic therapy combined with both RT and surgery or a higher dose of neck RT, were not associated with improved PFS or OS in these patients.

\section{Acknowledgments}

This study was supported by the Natural Science Doctoral Funding of Shandong province (No. ZR2017BH061) and the Funding of Qingdao Science and technology innovation plan (No. 17-1-1-54-jch).

\section{Disclosure}

The authors have no relevant conflicts of interest to disclose.

\section{References}

1. Chen SC, Chen MF, Hwang TL, et al. Prediction of supraclavicular lymph node metastasis in breast carcinoma. Int J Radiat Oncol Biol Phys. 2002;52:614-619. doi:10.1016/S0360-3016(01)02680-3

2. Jin R, Hu X, Luo J. Clinical characteristics and prognostic analysis of ipsilateral supraclavicular lymph node metastases in breast cancer patients: a retrospective study. Int J Clin Exp Pathol. 2019;12: 3526-3534.

3. Kiricuta IC, Willner J, Kolbl O, et al. The prognostic significance of the supraclavicular lymph node metastases in breast cancer patients. Int J Radiat Oncol Biol Phys. 1994;28:387-393. doi:10.1016/03603016(94)90062-0

4. Fan Y, Xu B, Liao Y, et al. A retrospective study of metachronous and synchronous ipsilateral supraclavicular lymph node metastases in breast cancer patients. Breast. 2010;19:365-369. doi:10.1016/j.breast. 2010.03.022

5. Singletary SE, Allred C, Ashley P, et al. Revision of the American Joint Committee on Cancer staging system for breast cancer. J Clin Oncol. 2002;20:3628-3636. doi:10.1200/JCO.2002.02.026

6. Giuliano AE, Connolly JL, Edge SB, et al. Breast cancer major changes in the American Joint Committee on Cancer eighth edition cancer staging manual. CA Cancer J Clin. 2017;67:290-303. doi:10.3322/caac.21393

7. Chen SC, Chang HK, Lin YC, et al. Prognosis of breast cancer after supraclavicular lymph node metastasis: not a distant metastasis. Ann Surg Oncol. 2006;13:1457-1465. doi:10.1245/s10434-006-9012-1
8. Strazzanti A, Gangi S, Trovato C, et al. Contralateral lymph node metastasis in a woman with new primary breast cancer: systemic disease or locoregional diffusion? Int $J$ Surg Case Rep. 2018;53:400-402. doi:10.1016/j.ijscr.2018.11.001

9. Grotenhuis BA, Klem TM, Vrijland WW. Treatment outcome in breast cancer patients with ipsilateral supraelavieular lymph node metastasis at time of diagnosis: a review of the literature. Eur J Surg Oncol. 2013;39:207-212. doi:10.1016/j.ejso.2012.11.002

10. Kim K, Kim SS, Shin KH, et al. Aggressive surgical excision of supraclavicular lymph node did not improve the outcomes of breast cancer with supraclavicular lymph node involvement (KROG 16-14). Clin Breast Cancer. 2020;20:51-60. doi:10.1016/j.clbc.2019.09.004

11. Kim K, Jeong Y, Shin KH, et al. Impact of regional nodal irradiation for breast cancer patients with supraclavicular and/or internal mammary lymph node involvement: a multicenter, retrospective study (KROG 16-14). Cancer Res Treat. 2019;51:1500-1508. doi:10. $4143 / \mathrm{crt} .2018 .575$

12. Pedersen AN, Møller S, Steffensen KD, et al. Supraclavicular recurrence after early breast cancer: a curable condition? Breast Cancer Res Treat. 2011;125:815-822. doi:10.1007/s10549-010-0918-8

13. Liu XJ, Wang J, Li W. Complications and safety of supraclavicular lymph node dissection in invasive breast cancer patients with ipsilateral supraclavicular lymph node metastasis. Chin J Bases Clin Gen Surg. 2016;23:1040-1043.

14. Sesterhenn AM, Albert US, Barth PJ, et al. The status of neck node metastases in breast cancer-loco-regional or distant? Breast. 2006;15:181-186. doi:10.1016/j.breast.2005.05.006

15. Bisase B, Kerawala C. Survey of UK practice for management of breast cancer metastases to the neck. Ann $R$ Coll Surg Engl. 2012;94:484-489. doi:10.1308/003588412X13171221591736

16. Chen S. Survival benefit of neck dissection for the patients with breast cancer with supraclavicular lymph node metastasis. J Clin Oncol. 2010;28:15s.

17. Jung JH, Kim SS, Ahn SD, et al. Treatment outcome of breast cancer with pathologically proven synchronous ipsilateral supraclavicular lymph node metastases. J Breast Cancer. 2015;18:167. doi:10.4048/ jbc.2015.18.2.167

18. Huang EH, Strom EA, Valero V, et al. Locoregional treatment outcomes for breast cancer patients with ipsilateral supraclavicular metastases at diagnosis. Int $J$ Radiat Oncol Biol Phys. 2007;67:490-496. doi:10.1016/j.jirobp.2006.08.040

19. Nikpayam M, Uzan C, Rivera S, et al. Impact of radical surgery on outcome in locally advanced breast cancer patients without metastasis at the time of diagnosis. Anticancer Res. 2015;35:1729-1734.

20. Ai X, Wang M, Li J, et al. Supraclavicular lymph node dissection with radiotherapy versus radiotherapy alone for operable breast cancer with synchronous ipsilateral supraclavicular lymph node metastases: a real-world cohort study. Gland Surg. 2020;2:329-341. doi:10.21037/gs.2020.03.09

21. Zhang W, Qi XM, Chen AX, et al. The role of supraclavicular lymph node dissection in breast cancer patients with synchronous ipsilateral supraclavicular lymph node metastasis. Chin J Oncol. 2017;39:374-379.

22. Chinese Anti-Cancer Association, Committee of Breast Cancer Society. Chinese expert consensus on the clinical diagnosis and treatment of advanced breast carcinoma (2018). Chin J Oncol. 2018;40:703-713.

23. NCCN Guidelines Version 1. 2020 Breast Cancer; January, 2020. Available from: https://www.nccn.org/professionals/physician_gls/ pdf/breast.pdf. Accessed January 2020.

24. Harms W, Budach W, Dunst J, et al. DEGRO practical guidelines for radiotherapy of breast cancer VI: therapy of locoregional breast cancer recurrences. Strahlenther Onkol. 2016;192:199-208. doi:10. 1007/s00066-015-0939-7

25. Lundstedt D, Gustafsson M, Steineck G, et al. Long-term symptoms after radiotherapy of supraclavicular lymph nodes in breast cancer patients. Radither Oncol. 2012;103:155-160. doi:10.1016/j.radonc. 2011.12.017 
26. Brito RA, Valero V, Buzdar AU, et al. Long-term results of combined modality therapy for locally advanced breast cancer with ipsilateral supraclavicular metastases: the university of texas M.D. anderson cancer center experience. J Clin Oncol. 2001;19:628-633. doi:10. 1200/JCO.2001.19.3.628

27. Livi L, Scotti V, Saieva C, et al. Outcome after conservative surgery and breast irradiation in 5717 patients with breast cancer: implications for supraclavicular nodal irradiation. Int $J$ Radiat Oncol Biol Phys. 2010;76:978-983. doi:10.1016/j.ijrobp.2009.03.001

28. Wu SG, Jia YS, Juan Z, et al. The value of radiotherapy in breast cancer patients with isolated ipsilateral supraclavicular lymph node metastasis without distant metastases at diagnosis: a retrospective analysis of Chinese patients. Onco Targets Ther. 2014;7:281-288.
29. Park HJ, Shin KH, Cho KH, et al. Outcomes of positron emission tomography staged clinical N3 breast cancer treated with neoadjuvant chemotherapy, surgery, and radiotherapy. Int J Radiat Oncol Biol Phys. 2011;81:689-695. doi:10.1016/j.ijrobp.2010.11.061

30. Skinner HD, Strom EA, Motwani SB, et al. Radiation dose escalation for loco-regional recurrence of breast cancer after mastectomy. Radiat Oncol. 2013;8:13. doi:10.1186/1748-717X-8-13

31. A multicenter, randomized, open-label prospective clinical trial to evaluate the clinical significance of supraclavicular lymph node dissection for breast cancer patients with ipsilateral supraclavicular lymph node metastasis. NCT03716245. Available from: https:/clin icaltrials.gov/ct2/show/NCT03716245. Accessed September 9, 2019.

\section{Publish your work in this journal}

Cancer Management and Research is an international, peer-reviewed open access journal focusing on cancer research and the optimal use of preventative and integrated treatment interventions to achieve improved outcomes, enhanced survival and quality of life for the cancer patient.
The manuscript management system is completely online and includes a very quick and fair peer-review system, which is all easy to use. Visit http://www.dovepress.com/testimonials.php to read real quotes from published authors. 